\title{
Current Status of Education and Training in Occupational Health and Their Development Programs in China
}

\author{
Xing GAO, Sutang LI, Xiaoyun WANG and Rui CHeng \\ Beijing Institute of Labour Hygiene and Occupational Diseases, Department of \\ Occupational Health, Ministry of Public Health. Beijing, China
}

\begin{abstract}
There are 40 post graduate schools of public health in China, from where 1,400 students are graduating every year. Fourteen percent of them are going into the occupational health field. A total of about 25,000 specialists are now working in the occupational health field. However, this number is only 1 percent of all health workers in China. Facts on the educational resources in China including responsible institutions and programs for such occupational health specialists are introduced and discussed. Finally a program for increasing the number of occupational health specialists in the Eighth Five-year Plan of China is introduced.
\end{abstract}

Key words: China, occupational health specialists, education and training.

(Received 15 February 1992, accepted 30 April 1992)

The development of national systems of education and training for the occupational health professions, is based on national and local occupational health needs and demands, integrated with occupational health care and education and training systems, with full utilization of the resources of universities and schools of occupational health personnel.

Education and training in occupational health have become of paramount importance during periods of accelerated change. The Chinese are now making great efforts to reorient their occupational health systems to primary health care as the key means of achieving health for all, under increasing difficult social economic conditions.

In the present system of education and training in occupational health, there is a network of interrelated elements embracing the workers, policies, plans, functions and facilities of several institutions and programs, which are working together to provide an opportunity for all occupational health workers to continue progressive learning throughout their careers. The ultimate aim is to improve the competence of all categories of occupational health workers and to aid the decision-makers at all levels of the occupational health delivery system who are involved or interested in organizing education and training for occupational health workers. In short, the aim is to improve the quality of 
occupational health provided by the whole range of occupational health workers.

Thus, the development of appropriate systems of education and training in occupational health for occupational health workers should be seen as one of the key strategies to be adopted to attain the goal of health for all citizens of the world by the year 2000 .

\section{The Present Status of Education in Occupational Health in China}

1. Higher Education Structure and Student Number Enrolled and Allocated

Forty schools of public health or divisions of preventive medicine are affiliated with 36 universities in China. The student enrollment number and that of graduation are shown in Tables 1 and 2.

Upon graduation, $15.8 \%$ of these students are assigned to work in the occupational health field in China. Whereas, graduates from 17 medical universities are assigned to occupational health institutions of different levels. For these statistics, see Table 3.

\section{Education System}

The State Education Commission (SEG) has decided that the system of higher education in medicine should be standardized and divided approximately into three systems. See Table 4.

\section{Number of Teachers in Occupational Health Education}

There were 544 teachers of occupational health in national medical universities and colleges in 1987. The figure is shown in Table 5.

\section{Structure of Special Field Courses}

Special field courses are divided into three parts; (1) basic courses - Health Chemistry, Health Statistics, Health Economics, Social Medicine, Health Microbiology, Experimental Pathology, etc. (2) special courses - Occupational Health and Occupational Diseases, Epidemiology, Food and Nutrition Health, Environmental Health, School Health, Endemic Disease and Health Toxicology, etc. (3) advanced courses (postgraduate students) Advanced Epidemiology, Advanced Health Statistics, Advanced Occupational Health and Occupational Diseases, Advanced Toxicology, and so on.

\section{Teaching Method for Practice}

Field work as a teaching method prepares students for work in the near future. As "worker-students", they find that their future work is similar to that of actual workers. Students and their teachers form working groups together to fulfill some important tasks set by the nation, to practice their duties as state workers and to prepare themselves to become 
Table 1. Number of enrolled students in universities and schools of public health

\begin{tabular}{cccc}
\hline Year & $\begin{array}{c}\text { Total enrollment } \\
\text { number }\end{array}$ & $\begin{array}{c}\text { Enrollment number } \\
\text { for public health }\end{array}$ & $\begin{array}{c}\text { Percent } \\
(\%)\end{array}$ \\
\hline 1983 & 30607 & 1489 & 4.6 \\
1984 & 33298 & 1802 & 5.4 \\
1985 & 40030 & 2161 & 5.4 \\
1986 & 38037 & 2287 & 6.0 \\
1987 & 41431 & 2398 & 5.8 \\
\hline
\end{tabular}

Table 2. Number of graduated students from universities and schools of public health

\begin{tabular}{cccc}
\hline Year & $\begin{array}{c}\text { Total graduation } \\
\text { number }\end{array}$ & $\begin{array}{c}\text { Graduation number } \\
\text { for public health }\end{array}$ & $\begin{array}{c}\text { Percent } \\
(\%)\end{array}$ \\
\hline 1983 & 33270 & 1273 & 3.7 \\
1984 & 28437 & 1456 & 5.5 \\
1985 & 27891 & 1453 & 5.2 \\
1986 & 26552 & 1221 & 4.6 \\
1987 & 30790 & 1598 & 5.2 \\
\hline
\end{tabular}

Table 3. Type of structure and proportion of staff by education

\begin{tabular}{|c|c|c|c|c|c|c|c|}
\hline \multirow[b]{3}{*}{ Structure } & \multirow[b]{3}{*}{ Total } & \multicolumn{6}{|c|}{ Record of formal schooling } \\
\hline & & \multicolumn{2}{|c|}{ Postgraduate } & \multicolumn{2}{|c|}{ Graduate } & \multicolumn{2}{|c|}{ Higher speciality } \\
\hline & & No. & $\%$ & No. & $\%$ & No. & $\%$ \\
\hline University & 120 & 19 & 63.3 & 97 & 18.4 & 4 & 8.5 \\
\hline Institute & 63 & 3 & 10.0 & 56 & 10.6 & 4 & 8.5 \\
\hline \multicolumn{8}{|l|}{ HAES $*$ of } \\
\hline Province & 78 & 1 & 3.3 & 73 & 13.9 & 4 & 8.5 \\
\hline City & 186 & 0 & 0.0 & 164 & 31.1 & 22 & 46.8 \\
\hline Country & 80 & 0 & 0.0 & 66 & 12.5 & 14 & 29.8 \\
\hline Others & 80 & 7 & 23.3 & 71 & 13.5 & 2 & 4.3 \\
\hline Total & 607 & 30 & 100.0 & 527 & 100.0 & 50 & 100.0 \\
\hline
\end{tabular}

* HAES: Health and Anti-Epidemic Station

Table 4. Length of education and degree

\begin{tabular}{cll}
$\begin{array}{c}\text { School } \\
\text { year }\end{array}$ & \multicolumn{1}{c}{$\begin{array}{c}\text { Record of } \\
\text { formal schooling }\end{array}$} & $\begin{array}{c}\text { Academic } \\
\text { degree }\end{array}$ \\
\hline 3 & Higher speciality & No \\
5 & Graduate & B. A. \\
7 & Postgraduate & M. S. \\
\hline
\end{tabular}

Table 5. Number of teachers in occupational health by academic rank

\begin{tabular}{lc}
\hline Academic rank & Number $(\%)$ \\
\hline Professor & $30(5.5)$ \\
Assoc. Prof. & $86(15.8)$ \\
Lecturer & $117(21.5)$ \\
Assist. Lectu. & $170(31.3)$ \\
Technician & $141(25.9)$ \\
\hline \multicolumn{1}{c}{ Total } & $544(100.0)$ \\
\hline
\end{tabular}


occupational health specialists. This quality-training method is expected to result in students developing the following abilities:

(1) Operative capability at workplace or laboratory

(2) Organization capability

(3) Capability in statistics

(4) Comprehensive capability

a. Organization

The center of the students' research group is the teacher, who is a responsible person and who is in charge of design, instruction and inspection of the subject. The students making up these research groups are considered to be assistants and not just students.

b. Programs

Look up documents.

Draw up, discuss, demonstrate the feasibility of putting a program into effect.

Prepare working conditions for experiment and workplace.

Prepare experiment.

Carry out a program.

Summarize, sort out data, treat data, statistical analysis, discuss summary report.

Complete article.

Revision of the paper upon critique.

Evaluation of achievement. practice evaluation $70 \%$ test paper evaluation $30 \%$

c. Evaluation of Benefits

Results for graduate students in 1984-1989:

Good professional morals and sense of responsibility $73 \%$

Capability of analyzing and solving problems $65.5 \%$

Ability of organizing epidemiologic and hygienic survey $55.9 \%$

Adaptation to workplace within 1.5 years $68.5 \%$ (within 1 year $36.1 \%$ )

\section{Occupational Health Structure, Resources and Training of Personnel}

1. Occupational Health Structure

Over 200 prevention, treatment and research institutions of occupational medicine have been established throughout the country and at the Ministry of Industries of the central government. Their development is seen chronologically in Table 6 .

The seven regional centers of industrial hygiene and occupational diseases were set up under the leadership of the Ministry of Public Health in 1983. Two WHO colllaborating 
centers of occupational health were established in the same year (Beijing, Shanghai). Since then, a primarily formulated preventive network of occupational health care has been inaugurated.

\section{Manpower Resources}

There are over 25,000 occupational health workers throughout the country, making up $1 \%$ of the national personnel. These occupational health personnel are organized at different levels. (Table 7)

Structure of post and rank of occupational health personnel is shown in Table 8 .

\section{Training}

a. Short Term Workshop

A course comprises a sequence of learning events planned to help occupational health workers to become more competent in new or more advanced methods. Such events include lectures, presentations by participants, role playing, visits to laboratories, experimental exercises, viewing and discussing films, and individual or group projects. For the schedule of a workshop in 1990, see Table 9.

Table 6. Chronological development of occupational institutions

\begin{tabular}{|c|c|c|c|}
\hline Year & Region & Structure & Number \\
\hline 1950 & Liaoning & Inst. of Occupational Health & 1 \\
\hline \multirow[t]{2}{*}{1951} & Shanghai & Inst. of Occupational Health & 1 \\
\hline & Anshan & Inst. of Occupational Health & 1 \\
\hline 1954 & Beijing & $\begin{array}{l}\text { Dept. of Occup. Health in } \\
\text { Inst. of Health in CAPM } *\end{array}$ & 1 \\
\hline 1959 & $\begin{array}{l}\text { Local } \\
\quad \text { goverments }\end{array}$ & Inst. of Occup. Health & $>100$ \\
\hline 1980 & $\begin{array}{l}\text { Ministry of } \\
\text { Industries }\end{array}$ & Inst. of Occup. Health & $>100$ \\
\hline
\end{tabular}

* Ghinese Academy of Preventive Medicine

Table 7. Occupational health structures and number of specialists

\begin{tabular}{lcc}
\hline Levels & $\begin{array}{c}\text { Number of } \\
\text { structures }\end{array}$ & Health personnel \\
\hline Province & 30 & 3956 \\
City & 361 & 5857 \\
County & 1905 & 12594 \\
Below county & 825 & 5155 \\
\hline \multicolumn{1}{c}{ Total } & 3121 & 27562 \\
\hline
\end{tabular}

Table 8. Number of occupational health personnel by post and rank

\begin{tabular}{cr}
\hline Post and rank & Number $(\%)$ \\
\hline Higher $*$ & $7695(30.1)$ \\
Middle & $12892(50.4)$ \\
Primary & $4997(19.5)$ \\
\hline * Professor, & Researcher, Physician, \\
Hygienist, Technician, Engineer and \\
Nurse.
\end{tabular}


Table 9. Workshops in 1990

\begin{tabular}{|c|c|c|c|c|}
\hline Subject & $\begin{array}{l}\text { Number of } \\
\text { participants }\end{array}$ & $\begin{array}{l}\text { Time } \\
\text { (hrs) }\end{array}$ & Object & Sponsor \\
\hline Industrial Hygiene & 30 & 60 & Industrial Hygienist & $\begin{array}{l}\text { Harbin School } \\
\text { of Public Health }\end{array}$ \\
\hline Occup. Medicine & 12 & 180 & $\begin{array}{l}\text { Physician of Occup. } \\
\text { Diseases }\end{array}$ & $\begin{array}{l}\text { Western China School } \\
\text { of Public Health }\end{array}$ \\
\hline Health Test & 40 & 60 & Health Chemist & Same as above \\
\hline $\begin{array}{l}\text { Management of Occup. } \\
\text { health in Village and } \\
\text { Downtown Industry }\end{array}$ & 40 & 90 & $\begin{array}{l}\text { Management of } \\
\text { Occup. Health }\end{array}$ & $\begin{array}{l}\text { Shanghai School } \\
\text { of Public Health }\end{array}$ \\
\hline $\begin{array}{l}\text { Preventive Health } \\
\text { Inspection }\end{array}$ & 60 & 50 & Industrial Hygienist & Same as above \\
\hline $\begin{array}{l}\text { Study on Occup. } \\
\text { Heaith Standards }\end{array}$ & 30 & 90 & $\begin{array}{l}\text { Physician Toxicologist } \\
\text { Hygienist }\end{array}$ & Same as above \\
\hline $\begin{array}{l}\text { Health Inspection and } \\
\text { Fulfilling Regulation }\end{array}$ & 60 & 12 & $\begin{array}{l}\text { Administrator of } \\
\text { National Occup. } \\
\text { Health Structure }\end{array}$ & $\begin{array}{c}\text { Chinese Association } \\
\text { of Health Law }\end{array}$ \\
\hline $\begin{array}{l}\text { Monitoring Dosage of } \\
\text { Air Pollution for } \\
\text { Exposed Workers }\end{array}$ & 40 & 6 & $\begin{array}{l}\text { Hygienist Health } \\
\text { Chemist }\end{array}$ & $\begin{array}{l}\text { Inst. of Environmental } \\
\text { Health }\end{array}$ \\
\hline
\end{tabular}

b. Adult Education

The main aim of the following adult educational courses is to enable adults to acquire a specific certificate or record of formal schooling.

Evening College

Correspondence Course

Television Gollege

Worker Medical College

c. Advanced Learning Abroad, Sponsored by WHO or/and SEC

d. Degree Education

Master degree (M. S.)

Doctorate (M. D.)

\section{Development Programs for the National Occupational Health Workers during the "Eighth Five-Year-Plan"}

Guidance for improving occupational health education: Increasing personnel engaged in the occupational health system and training them at their work:

To carry out the main principle that all universities and colleges should make an effort to train personnel in occupational health.

To carry out the principle that occupational health education should spread to 
grassroots levels and try to solve their problems taking the special circumstances of the country into consideration.

To carry out the educational principle that students should be sent to do field work so that personnel at different levels will be trained in occupational health.

\section{Targets}

a. In accordance with the principle of "The different levels of regulations on health and anti-epidemic organizational establishment" by the National Establishment Committee, the Ministry of Public Health allocates students to occupational health institutions at different levels. Some students are sent to the grassroots activities, such as Street Prevention and Protective groups and stations attached to different occupational health structures.

b. The percent of the educational level of technicians at different occupational health structures are seen in Table 10.

c. Personnel will be trained scientifically and technically in special fields such as research, management and foreign language capability. They will become the new administrators in the future. Some of them will become professors, physicians and researchers in the development of occupational health both abroad and at home.

d. The new leaders at different levels will bring new blood to the development of social medicine, health management, health economy and occupational health.

e. The occupational health workers at the middle levels are trained full-time in universities for a period of time that is in accordance with practical needs. They not only gain some new knowledge but also grasp basic principles of health statistics and occupational epidemiology. Some surveys show that this training rate has reached up to $100 \%$.

f. The occupational health workers at primary levels mainly receive special course training, who, because of their lack of schooling, are sent to some vocational schools

Table 10. Proportion of occupational health specialists by educational background and region of structure

\begin{tabular}{lccccc}
\hline \multicolumn{1}{c}{ Region } & $\begin{array}{c}\text { Postgraduate } \\
(\%)\end{array}$ & $\begin{array}{c}\text { University } \\
\text { graduate }(\%)\end{array}$ & $\begin{array}{c}\text { Higher education } \\
\text { graduate }(\%)\end{array}$ & $\begin{array}{c}\text { Secon. } \\
\text { graduate }(\%)\end{array}$ & Primary \\
\hline Province & $2-3$ & $45-47$ & $15-20$ & $30-38$ & - \\
City & 0.5 & $15-20$ & $20-30$ & $50-65$ & - \\
County & - & $5-8$ & $8-10$ & $43-52$ & $30-40$ \\
Village & - & - & - & 50 & 50 \\
\hline
\end{tabular}


so as to do some primary work as a part time worker.

g. Some provinces have established training centers to which they allocate students according to practical situations. Schools of Public Health and Health and AntiEpidemic Stations (HAES) together with training centers make up the four levels in the training network.

Quality control work for correspondence courses and a special correspondence enrollment certificate must be developed. Around 2,000-3,000 learning personnel are enrolled in these courses throughout Ghina.

\section{Measures}

a. To develop resources of occupational health manpower under the support of the State Education Commission and the State Planning Committee, more students should be enrolled in schools of public health or/and divisions of preventive medicine in medical universities and special field bases should be increased. Further efforts should be made to guarantee that a certain number of students will be enrolled in medical universities and also that some of the graduates should be transferred to higher educational courses in special fields. With these efforts, personnel at different levels will be maintained for the institutions concerned.

b. Occupational health structures at different levels are responsible for finding field work for students and compiling practical textbooks, fulfilling work requirements, selecting teachers, assessing post and rank, practicing facilities and so on. In any future promotion, the fact that whether the students can fulfill their assigned tasks in the field work will be taken into consideration.

c. To enhance the continuing education and training of occupational health workers working part-time without degrees, the training at the workplace for occupational health workers will be brought into the general training projects at the different levels for occupational health personnel under the leadership of the Preventive Department, Health Inspection Department, and Educational Department of the Ministry of Public Health.

The Chinese Academy of Preventive Medicine and Schools of Public Health and Divisions of Preventive Medicine, medical universities and advanced departments at HAES in all parts of the provinces, regions and cities are undertaking training programs for special occupational health structures in order to improve the actual levels of scientific research, and the managerial skills of occupational health personnel. Organizations at the provincial level are in charge of training special mainstays at regional or/and municipal levels. It will be accomplished primarily 
during the "Eighth five-year plan" and the training for administration leaders of the new generation will be undertaken during the "Ninth five-year plan."

d. To establish training centers for the occupational health personnel in provinces, the full use of present training bases in regions, cities and counties that focus on training above special primary health personnel (e. g. occupational medical house physician, etc.), and which fully give play to conditions of health schools in counties and institutions of occupational health must be considered. Emphasis should be put on training technicians, nurses and workers who have no records of formal schooling in their field. Chances should be given them to acquire a record of formal schooling at the secondary health school level (or equal to its level). This can be acomplished by increasing the number of health personnel in HAES.

e. To increase workers' educational records of formal schooling, continuing efforts should be made at colleges and secondary schools so that workers will have more chances to obtain formal education. Running high-level special education courses and granting a special certificate for successful results of those completing correspondence education will make it possible for those with education at secondary school level or higher.

f. Training programs for occupational health must be planned in accordance with local education and should be supported financially and administratively. Organization management should be strengthened. Training of health personnel and vocational education are two of the main tasks in health administration. Departments of Prevention, Science and Education are mainly engaged in the training tasks of occupational health, determine training programs, and predict different categories of occupational health personnel.

g. To determine policies and promote training of occupational health personnel. The governments of provinces and cities must carry out the spirit of Document No. 16 of the National Council conscientiously. The implementation of occupational health specialists in the different health care structures should focus on university (and college) and secondary health schools. Persons who have not been trained in any special field are not permitted to engage in health care specialities nor to take part in decision-making.

h. Training must be relative to formal schooling records, determining standards required for occupational health specialists at different levels, persisting evaluation system, encouraging self-learning at workplace, and improving their knowledge. 
中国における労働衛生専門家の教育，訓練の現状と拡充政策

Xing GAO, Sutang LI, Xiaoyun WANG and Rui CHENG

Beijing Institute of Labour Hygiene and Occupational Diseases, Department of Occupational Health, Ministry of Public Health. Beijing, China

要旨：中国には現在公衆衛生大学院が 40 校あり, 年間約 1,400 人の卒業生の内約 $15 \%$ が労働 衛生分野で衝いている．現在全国で 25,000 人の労衝衛生專門家が活躍しているが，これ は全医療従事者の約 $1 \%$ にぎない。これら労働衛生専門家の教育機関，所属機関の現状 について統計的な紹介をし，教育カリキュラムを概説した，最後に現在進行中の第 8 次 5 力年計画で行われている労衝衛生専門家の数を増加するための方策を論じ，1）まず公 衆衛生大学院の学生を増やし，2）地域では実地修練の場を確保し，3）現在，他の職業 に就いている人が㗢きながら勉強できるようにし，4）省単位に養成施設を整備するとと もに，5）これらの教育，訓練が地域に扔ける通常の基礎教育の内容と整合性が図られる 必要のあることを指摘した。

J UOEH（産業医大誌）14 ( 3 ) 241－250 (1992) 